\title{
Çekin İbrazında Mücbir Sebepler: COVID-19 Salgını Örneğinde TK M 811 Hükmünün Değerlendirilmesi
}

\author{
Koray Demir ${ }^{*}$ (1)
}

Öz

Çekin ibrazında mücbir sebepler meselesi Türk Ticaret Kanunu'nun (“TK") 811. maddesinde düzenlenmiştir. Mücbir sebep, niteliği itibariyle kişinin mücbir sebep süresince yükümlülüklerinin ifasını imkânsız hale getirmekte ve bu mükellefiyetlerinden geçici süreyle kurtulması sonucunu doğurmaktadır. Bu manada TK $m 811$ hükmünün özü, hamilin ibraz süresi içerisinde muhatap bankaya ödeme talebi ile başvuramamış olmasının bir mücbir sebebe dayanması halinde anılan sürelerin mücbir sebep ortadan kalkıncaya kadar uzayacağını öngörmekten ibarettir. Ancak tahlile konu hüküm şimdiye kadar yeterli uygulama alanı bulamamıştı; hükümde geçtiği haliyle hangi vakaların mücbir sebep olarak kabul edilebileceği, güncel COVID-19 salgınının bu kapsamda mücbir sebep olarak görülüp görülemeyeceği ve hükmün ikinci fikrasında öngörülen ihbar ve kayıt şartının mutlak olup olmadığı gibi soruların cevaplanması gerekmektedir. Aynı şekilde COVID-19 salgını özelinde TK m 811 hükmünün 7226 sayılı Kanun'un Geçici 1. maddesi ile ilişkisinin de incelenmesi icap edecektir. Burada temsil olunan görüş uyarınca, güncel COVID-19 salgını TK $m 811$ hükmü anlamında bir mücbir sebeptir. Salgın nedeniyle çekin ibrazında yaşanabilecek gecikmeler dolayısıyla TK $m 811$ hükmünün uygulanması gerekir. 7226 sayılı Kanun'un Geçici 1. maddesi anılan hükmün yorumu ve tamamlanmasında kullanılabilir. TK m 811/2 hükmünde geçtiği haliyle inbar ve kayıt şart da mutlak değildir.

\section{Anahtar Kelimeler}

Çek, ibraz, ibraz süreleri, Mücbir sebep, ihbar ve kayıt şart

Force Majeure Events Affecting the Check Presentation: Evaluation of Article 811 TCC Using the Example of COVID-19 Pandemic

\begin{abstract}
Force majeure events affecting the presentation of a check are regulated by Article 811 TCC. Force majeure events can generally be defined as events that (temporarily) make it impossible to fulfill any obligations, and thus, the obligations pend during the force majeure events. Article 811 TCC stipulates that the holder of a check affected by a force majeure event may present the check later without losing any of his or her rights. It reflects the general understanding of the force majeure institution and has been exercised in a few cases until now. Therefore, some questions, such as which events shall be deemed to be a force majeure event under the terms of Article 811 TCC, whether the coronavirus disease 2019 (COVID-19) pandemic hinders the holders of a check to present it, and whether the notification and recording obligation of the holder as it is foreseen in the second paragraph of Article 811 TCC is absolute, are still unaddressed. The relation of Article 811 TCC with the interim Article 1 of Law Nr 7226 with respect to the COVID-19 pandemic also needs to be highlighted. Against this background, this paper deals with the aforementioned questions and comes inter alia to the following conclusions: COVID-19 pandemic is a force majeure event in terms of Article 811 TCC. Article 811 TCC should be applied in the cases of the delays of check presentation instead of the interim Article 1 of Law Nr 7226. The interim Article 1 of Law Nr 7226 can however be used to interpret and complement Article 811 TCC. Finally, the notification and recording obligation of the holder as it is foreseen in the second paragraph of Article 811 TCC are not absolute.
\end{abstract}

\section{Keywords}

Check, Presentation, Presentation period, Force majeure, Notice and recording requirement

* Sorumlu Yazar: Koray Demir (Doç. Dr.), Türk-Alman Üniversitesi, Hukuk Fakültesi Ticaret Hukuku Anabilim Dalı, İstanbul, Türkiye. E-posta: k.demir@tau.istanbul.edu.tr ORCID: 0000-0001-8447-1229

Atrf: Demir K, “Çekin ibrazında Mücbir Sebepler: COVID-19 Salgını Örneğinde TK M 811 Hükmünün Değerlendirilmesi” (2020) 78(2) İstanbul Hukuk Mecmuası 417. https://doi.org/10.26650/mecmua.2020.78.2.0006 


\section{Extended Summary}

The holder of a check is obliged to present it at the addressee bank and ask for the payment within a general period of 10 days; if not, he or she inter alia loses his or her regress rights. However, the holder may have to hold back from presenting the check due to the occurrence of an event that was not in his or her control that may be deemed to be a force majeure event. In such cases, Article 811 TCC stipulates that without losing any rights, the holder of a check affected by a force majeure event may present the check after its extinction. Hence, Article 811 TCC reflects the general understanding of the force majeure institution, that is, the obligation to present a check at the addressee bank and ask for the payment pends during a force majeure event.

However, Article 811 TCC needs to be highlighted in many ways because it could not be exercised sufficiently until now. For instance, some questions still seem to be unaddressed, such as which event shall be deemed to be a force majeure event under the terms of Article 811 TCC, whether the coronavirus disease 2019 (COVID-19) pandemic hinders the holders of a check to present it, and whether the notification and recording obligation of the holders as it is foreseen in the second paragraph of Article $811 \mathrm{TCC}$ are absolute. The relation of Article $811 \mathrm{TCC}$ with the interim Article 1 of Law $\mathrm{Nr} 7226$ with respect to the COVID-19 pandemic also needs to be highlighted.

In our opinion, the COVID-19 pandemic shall be deemed to be a force majeure event in terms of Article 811 TCC. Some may doubt this opinion because the banks were open during the pandemic. However, we believe that a force majeure event is not an absolute hindrance that cannot come to an end at any cost. Hence, the holders of a check might have brought it to the addressee bank. However, we should ask the question "at what cost?" to evaluate such a case and come to a general conclusion that banks being operational should not hinder us from marking the pandemic as a force majeure event because the law shall not ask its addressees to risk their lives merely not to lose any of their rights. Comparative studies in German law also support this viewpoint.

Furthermore, in our opinion, the notification and recording obligation of the holder as it is foreseen in the second paragraph of Article 811 TCC are not absolute because this paragraph is a contradiction in itself. Due to the force majeure event, the lawmaker excuses the holders of a check to present it at the addressee bank. However, the same lawmaker asks them to visit a notary public during the pandemic to notify the force majeure event. In addition, comparative studies reveal that in cases of an unknown event, the said notification requirement was just deemed to be necessary. We may thus agree that the COVID-19 pandemic is known by the others involved in the check relation. 
Finally, because Article $811 \mathrm{TCC}$ is a special norm in comparison to the interim Article 1 of Law Nr 7226, we believe that the former should be applied to the cases of the delays of check presentation and not the latter. As may be known, special norms always take precedence and can be applied even when they are old. However, the interim Article 1 of Law $\mathrm{Nr} 7226$, on which the holders of a check may lean, contains for instance the dates of the pandemic; thus, it may be used to interpret and complement Article $811 \mathrm{TCC}$ in this sense. 


\section{Çekin İbrazında Mücbir Sebepler: COVID-19 Salgını Örneğinde TK M 811 Hükmünün Değerlendirilmesi}

\section{Giriş}

Çekin ibrazında mücbir sebepler meselesi Türk Ticaret Kanunu'nun (“TK”) 811. maddesinde düzenlenmiştir. Bilindiği üzere çekler, belirli süreler içerisinde muhatap bankaya ödeme talebiyle ibraz edilmek durumundadırlar (TK m 796) ${ }^{1}$; çekin söze konu süreler içinde ibraz edilmemesi ise, diğerleri yanında, hamilin kambiyo hukuku çerçevesinde kendisinden önce gelen cirantalar ile keşideciye karşı sahip olduğu rücu/başvuru haklarının kaybı ile neticelenir ${ }^{2}$. Bu çerçevede TK m 811 hükmünün özü, hamilin ibraz süresi içerisinde muhatap bankaya ödeme talebi ile başvuramamış olmasının bir mücbir sebebe dayanması halinde anılan sürelerin mücbir sebep ortadan kalkıncaya kadar uzayacağını öngörmekten ibarettir. Mücbir sebep niteliği itibariyle kişinin mücbir sebep süresince yükümlülüklerinin ifasını imkânsız hale getirmekte ve ifa mükellefiyetinden geçici süreyle kurtulması sonucunu doğurmaktadır ${ }^{3}$. TK m 811 hükmü de bu manada hukukun mücbir sebebe bağladığı genel sonuç ile uyumludur.

Tahlile konu TK m 811 hükmü 6762 sayılı Türk Ticaret Kanunu'nun (“eTK”) 723. maddesinin halefidir ve lafzı bakımından anılan maddeyi sadeleştirerek tekrar etmektedir. Ancak her iki hüküm de şimdiye kadar yeterli uygulama alanı bulamamıştır. Görülebildiği kadarıyla TK m 811 hükmü henüz hiç Yargıtay önüne gelmemişken, eTK m 723 hükmü de sadece yedi olayda yüksek mahkemece değerlendirilebilmiştir ${ }^{4}$.

TK m 811 hükmünün muadilleri İsviçre ve Alman hukuk sistemlerinde de mevcuttur. Bu manada, İsviçre Borçlar Kanunu'nun ("İsvBK") 1131. maddesi ${ }^{5}$ ile Alman Çek Kanunu'nun (“AlmÇekK”) 48. maddesinin' lafız yönünden TK m 811 hükmü ile birebir örtüştüğünü ifade etmek mümkündür. Ancak mezkûr hükümler de şimdiye kadar yeterli uygulama alanı bulamamışlardır. $\mathrm{Bu}$ yönüyle İsvBK $\mathrm{m}$ 1131 hükmünün şimdiye kadar hiç uygulanmadığ1, AlmÇekK m 48 hükmünün ise, özellikle 2. Dünya Savaşı'nın bitimini müteakip sadece üç kere Yüksek Eyalet veya Federal Mahkeme seviyesinde ele alındığı anlaşılabilmektedir.

\footnotetext{
İbraz süreleri dolayısıyla farklı görüşler için bkz Fırat Öztan, Klymetli Evrak Hukuku (17. Bası, Turhan 2012) 285 vd; Abuzer Kendigelen, Çek Hukuku (5. Bası, On İki Levha 2019) 278 vd; Hüseyin Ülgen, Mehmet Helvac1, Arslan Kaya ve N Füsun Nomer Ertan, Klymetli Evrak Hukuku (12. Bas1, Vedat 2019) 322 vd.

2 Örnek kabilinden ve diğer sonuçlar için de bkz. Ali Bozer ve Celal Göle, Klymetli Evrak Hukuku (7. Bası, BTHAE 2017) $343 \mathrm{vd}$.

3 Dannecker ve Biermann, Vorbemerkungen zu Art. 23 f: Unionsrechtliche Geldbussen und Zwangsgelder, Immenga/ Mestmäcker, Wettbewerbsrecht (6. Auflage, Beck 2019) N 171.

4 Uygulamadan örnekler için bkz. Gönen Eriş, Klymetli Evrak (2. Bask1, Seçkin 2016) 1220; Seza Reisoğlu, Çek Hukuku (1. Bask1, Cem 2011) 206 vd.

5 Madde metni ve kısa açıklama için bkz. Hans Kuhn, "Art. 1131”, CHK-Handkommentar zum Schweizerischen Privatrecht, (Orell Füssli 2016) 1030 vd.

6 Madde metni ve kısa açıklama için bkz. Peter Bülow, "Art. 48 ScheckG”, Wechselgesetz, Scheckgesetz (5. Auflage, Beck 2013) N $1 \mathrm{vd}$.
} 
Hükmün bu denli az kullanılmasının temelinde, bir çekin ibrazını engelleyecek şekilde salgın, terör saldırısı veya savaşların, çok şükür, sıkça yaşanmaması yatmaktadır. Ancak güncel COVID-19 salgını da göstermiştir ki, TK m 811 ve muadili hükümler üzerinde de er geç tefekkür etmek gerekebilmektedir.

İşte bu noktada huzurdaki çalışmanın amacı TK m 811 hükmünün ülkece yaşamakta olduğumuz salgın örneğinde değerlendirilmesidir. Bu manada anılan hükmün uygulanma koşullarının neler olduğu, hükümde geçtĭgi haliyle mücbir sebepten ne anlaşılacağı, 7226 sayılı Kanun'un Geçici 1. maddesi ile TK m 811 hükmünün ilişkisi, tahlile konu maddenin ikinci fikrasında öngörülen ihbar ve kayıt yükümlülügünün işlevi ve bir zorunluluk arz edip etmediği gibi soruların çalışma içerisinde ele alınmasına gayret gösterilecektir. Ancak öncesinde TK m 811 hükmünün uygulama alanının tespit olunması gerekmektedir.

\section{Hükmün Uygulama Alanı}

\section{A. Kişisel Uygulama Alanı}

TK m 811 hükmü hamilin haklarını koruyucu nitelikte bir düzenlemedir. Hükmün temelinde, yukarıda da ifade olunduğu üzere, mücbir sebeple ibraz sürelerini kaçırmış olması karşısında hamilin hak kaybına uğramasının engellenmesi gayesi yatmaktadır. Bu yönüyle hükmün kişisel odağı hamildir.

$\mathrm{Bu}$ haliyle tahlile konu hüküm muhatabın ve keşidecinin mücbir sebep süresince uyması lazım gelen hususlar konusunda suskun kalmaktadır. Örneğin muhatap banka mücbir sebep ortadan kalkmadan kendisine ibraz edilen bir çek karşısında ne yapacaktır? Yasanın (normal zamanlarda) emrettiği gibi çek hesabında karşlık olup olmadığını kontrol edip karşı1ık varsa ödeme yapıp, karşılık yoksa da çekin arkasına karşılıksızlık vakıasını tevsik eden bir kayıt mı düşmesi gerekecektir? Ya da keşideci, keşide tarihini takip eden günden başlamak üzere örneğin sadece on gün boyunca çek hesabında karşl1ık bulundurmak zorundayken, şimdi mücbir sebeple "uzayan" ibraz süreleri içerisinde de hesapta karşılık bulundurmak zorunda kalacak mıdır? Bu manada hüküm, mücbir sebep dolayısıyla ortaya çıkabilecek tüm soru ve sorunların cevabını içermemekte, sadece mücbir sebep olgusunu başvuru haklarının yitirilmemesi meselesi tahtında ele almaktadır.

Esasen yukarıda verilen soru ve sorunlar huzurdaki çalışmanın konusunu oluşturmamaktadır. Son dönem çıkan yayınlarda bu soru ve sorunların tafsilatıyla ve münazaalı bir biçimde ele alındığ görülmektedir. Dolayısıyla bu noktada ilgili 
eserlere atıfla yetinilebilecektir ${ }^{7}$. Ancak yine de k1saca ifade etmek gerekir ki, yukarıda anılan sorular bakımından hukukun mücbir sebebe bağladığg genel sonuçlar üzerinden ve TK m 811/1 hükmünde geçtiği haliyle "uzama" ifadesinin "kesilme", "durma" şeklinde anlaşılması ile de adil çözümlere ulaşılabilecektir. Buradan kasıt özellikle şudur: Yukarıda da ifade olunduğu üzere mücbir sebep, kendisinden etkilenen herkesin tabi olunan mükellefiyetlerinden mücbir sebep boyunca kurtulmas1, bu mükellefiyetlerin anılan süre boyunca askıya alınması sonucunu doğurmaktadır. $\mathrm{O}$ nedenle keşidecinin de mücbir sebep süresince hesapta karşılık bulundurmak yönünde bir mükellefiyetinin bulunmadığı, bu mükellefiyetin askıya alındığı ifade olunabilir. $\mathrm{Bu}$ nedenle kanaatimizce, mücbir sebep boyunca, her ne şekilde olursa olsun, bankaya ibraz edilebilmiş çeklere de karşılıksızlık müeyyidesinin uygulanamaması icap edecektir.

Aynı şekilde TK m 811/1 hükmünde geçtiği haliyle "uzama” ifadesinden ibraz sürelerinin kesilmesi anlaşılacak olursa, bankaların da mücbir sebep ortadan kalkmadan ibraz olunan çekleri herhangi bir işlem yapmaksızın iade edecekleri sonucuna varılabilir. Kanaatimizce hükümde kullanılan uzama ifadesinden kesilme veya durmayı anlamak gerekir. Bu kanaati destekleyen hususlardan ilki Yargitay’ın şimdiye kadarki uygulamasıdır. Örneğin Yargıtay 12. Hukuk Dairesi, önüne gelen iki olayda hükümde geçen uzama ifadesini kesilme olarak anlamış ve uygulamıştır ${ }^{8}$. Anılan her iki vaka da aynı hamilin vefatına ilişkindir. Hamil 23.12.2005 tarihinde vefat etmiş, elinde mevcut iki adet 26.12.2005 keşide tarihli çek 28.12.2005 tarihinde tereke mahkemesi kasasında muhafaza altına alınmış, söze konu çekler 17.01.2006 tarihinde mirasçılara teslim edilmiş ve mirasçılar da çekleri 23.01.2006 tarihinde muhatap bankaya ibraz edebilmişlerdir. Yargıtay her iki olayda da çeklerin tereke mahkemesi kasasında muhafaza altına alınmasını mücbir sebep saymış ve esasen çeklerin keşide tarihi üzerinden yaklaşık bir ay geçmiş olmasına rağmen bankaya yapılan ibrazın on günlük ibraz süresi içerisinde olduğuna kanaat getirmiştir. $\mathrm{Bu}$ haliyle Yargıtay çekin ibraz süresini mücbir sebep itibariyle kesmiş ve mücbir sebebin ortadan kalkmasını müteakip yeniden işletmeye başlamıştır.

Esasen hükümde geçen uzama ifadesinden kesilme veya durmanın anlaşılması gerektiği şeklindeki bir yorumu güncel COVID-19 salgını dolayısıyla yürürlüğe giren 7226 sayılı Kanun’un Geçici 1. maddesi de desteklemektedir. Orada da öngörüldüğü üzere, çekte ibraz sürelerini de kapsayacak şekilde tüm ibraz süreleri 13 Mart 2020

Bkz. Ali Paslı, “COVID-19 Salgınının Çek Hukukuna Etkisi: Güncel Koşullar Sürerken Çek İbrazı Mümkün müdür?” http:// www.ticaretkanunu.net/ali-pasli-covid-19-salgininin-cek-hukukuna-etkisi-guncel-kosullar-surerken-cek-ibrazi-mumkunmudur Erişim Tarihi 15.05.2020; Alihan Aydın, "COVID-19 Salgını ve 7226 Sayılı Kanunun Geçici 1. Maddesi Çekten Kaynaklanan Hukuki Sorumluluğun Şartlarını Değiştirmiş midir?” https://blog.lexpera.com.tr/covid-19-salgini-ve-7226sayili-kanunun-gecici-1-maddesi-cekten-kaynaklanan-hukuki-sorumlulugun-sartlarini-degistirmis-midir Erişim Tarihi 15.05.2020; H. Ali Dural, “COVID-19 Salgını Nedeniyle Yürürlüğe Giren 7226 Sayılı Kanun’un Geçici 1. Maddesinin Çek Açısından Sonuçları” https://blog.lexpera.com.tr/covid-19-salgini-nedeniyle-7226-sayili-kanunun-cek-acisindan-sonuclari Erişim Tarihi 15.05.2020.

8 Bkz. Yargıtay 12 HD, 18973/21737, 21.11.2006; 70/3123, 23.02 .2007 (Kazancı İçtihat Bilgi Bankası). 
tarihi itibariyle durmuştur ve en erken 15 Haziran 2020 tarihi itibariyle yeniden işlemeye başlayacaktır.

Son olarak muhatap bankanın ödeme yükümlülüğünün esasen keşideci ile arasında mevcut çek sözleşmesine istinat ettiği ve hamilin bu nispi sözleşmeye dayanarak muhatap bankadan talepte bulunamayacağı hususu da göz önünde bulundurulursa ${ }^{9}$, bankaların aynı zamanda müşterileri olan keşidecilerinin duçar olduğu mücbir sebep dolayısıyla bu sebebe dayanarak çek üzerinde herhangi bir işlem tesisini reddetmeleri de sözleşmeye uygun davranış olarak ortaya çıkacaktır. Uygulamada da bazı bankaların şu sırada, kanaatimizce doğru bir biçimde, kendilerine ibraz olunan çekler dolayısıyla işlem tesis etmedikleri, çeklere "mücbir sebep" kaşesi basmakla yetindikleri görülmektedir.

\section{B. Hükmün 7226 Sayılı Kanun'un Geçici 1. Maddesi ile İlişkisi}

TK m 811 hükmünün uygulama sahası başlığı altında güncel COVID-19 salgını nedeniyle izahı gereken bir diğer husus da hükmün 7226 sayılı Kanun'un Geçici 1. maddesi ile ilişkisidir. Bu noktada 7226 sayılı Kanun'un COVID-19 salgını özelinde çıarılmış, TK'ya nazaran yeni bir kanun olduğu ve TK m 811 hükmünün uygulanmasını dışladığı şeklinde bir düşünce hâsıl olabilir. Ancak burada temsil olunan görüş uyarınca 7226 sayılı Kanun'un Geçici 1. maddesi TK m 811 hükmünü dışlamamaktadır. Çünkü anılan hüküm çekin ibrazında cari sürelerin kaçırılması bakımından 7226 sayılı Kanun'un Geçici 1. maddesine nazaran özel hüküm niteliğindedir ve bilindiği üzere özel hüküm de, eski tarihli bile olsa, genel hükme galebe çalar. 7226 say1lı Kanun'un Geçici 1. maddesinin sadece ibraz sürelerinin durduğunu ve yeniden başlama tarihini tespit etmekte olduğu, diğer hususlarda suskun kaldığı ve uygulamada çekin ibrazı dolayısıyla baş gösterebilecek sorunların tamamına cevap vermediği de unutulmamalıdır. $\mathrm{Bu}$ manada kanaatimizce çekte mevcut ibraz sürelerinin kaçırılması merkezli ihtilaflarda halen TK $m 811$ hükmünün öncelikli olarak uygulanması icap edecektir.

Ancak bu noktada hemen şu hususu da eklemek gerekir: COVID-19 salgını nedeniyle yürürlüğe konan 7226 sayılı Kanun'un Geçici 1. maddesi, yukarıda verilen ilk örnekte olduğu gibi ve takip eden başlıklar altında yenilerinin de gösterilmeye çalışılacağı üzere, TK m 811 hükmünün yorumunda ve/veya tamamlanmasında yardımcı olabilecek niteliktedir. Örneğin birazdan da ele alınacağı üzere, TK m 811/1 hükmü bir mücbir sebebin varllğının ve süresinin ortaya konulması hususunu hamilden beklemektedir. Bu noktada 7226 sayılı Kanun'un ilgili maddesi hem bir mücbir sebebin varlığına, hem de süresine ilişkin hamile yardımcı olabilecek bir kaynak niteliğindedir.

Ayrıntısı ve Çek Kanunu ile ilişkisi için bkz. Ülgen/Helvacı/Kaya/Nomer Ertan (n 1) 315 vd. 


\section{Hükmün Unsurları}

TK m 811 hükmü beş fikradan ibarettir. Hükmün 1. fikrası hükmün ilk ve en önemli unsuru ile buna bağlanan hukuki sonucu ele almaktadır. Bu manada hükmün en önemli unsuru mücbir sebeptir ve buna bağlanan sonuç da ibraz sürelerinin uzaması ya da burada temsil olunan görüş uyarınca kesilmesidir. Hükmün 2. fikrası mücbir sebebin gecikmeksizin ihbarını ve çek üzerine de kaydını şart koşmaktadır. Bu manada TK m 811/1 hükmünde öngörülen ibraz sürelerinin kesilmesi sonucunun doğabilmesi bir ihbar ve kayıt şartına bağlanmıştır. Hükmün 3. ve 4. fikralarında mücbir sebebin ortadan kalkması veya belirli bir süreyi aşması halinde çekin ibrazı meselesi ele alınmaktadır. Hükmün son fikrası ise, esasen 1. fikrada geçen mücbir sebep ifadesini açıklamaya yönelik bir tanım hükmüdür. Bu manada tahlile konu TK m 811 hükmünün unsurlarını mücbir sebep, ihbar ve kayıt mükellefiyeti ve ibraz olarak belirlemek mümkündür.

\section{Mücbir Sebep}

Hukukta mücbir sebep şu üç alt unsur üzerinden tanımlanmaktadır ${ }^{10}$ : Mücbir sebebin sebebe yaslanan kişinin etki alanı dışında gelişmiş olması, engellenememesi ve üstesinden de gelinemeyecek nitelikte olması.

Mücbir sebebin, sebebe yaslanan kişinin etki alanı dışında gelişmiş olmasından mücbir sebebin en yüksek özen gösterilse dahi gerçekleşecek bir tesadüf olması gerektiği, devamla mücbir sebebe yaslanan kişinin mezkûr olayın ortaya çıkışında en ufak da olsa bir kusurunun bulunmaması gerekliliği anlaşılır.

Mücbir sebebin engellenememesinden ise, tahlile konu olayın s1k tekrar etmemesi, bir anda zuhur etmesi, daha önceden (pek) bilinmediği ve tahmin de edilmediği için herhangi bir tedbirin alınamaması anlaşılır. Örneğin İsviçre Federal Mahkemesi, önüne gelen iki olayda dağlık bölgelerde bahar mevsiminde sıcak ve yoğun yağışın sıklıkla görülmesi dolayısıyla tahliye kanallarının buna göre daha geniş tutulması sayesinde önlenebilecek nitelikteki ağır yağış olgusunu mücbir sebep olarak kabul etmemiştir ${ }^{11}$.

Son olarak bir vakanın mücbir sebep olarak addedilebilmesi için söze konu engelin üstesinden gelinmesinin anılan olguya istinat eden şahıstan makul bir biçimde beklenememesi gerekmektedir. Buradan kasıt tahlile konu kişinin sübjektif şartları itibariyle, mücbir sebep olarak yaslandığı vakanın üstesinden gelemeyecek olması ve bu türden bir beklentinin objektif manada da makul olmamasıdır. Bu minvalde mücbir sebep objektif nitelikte bir ifa imkânsızlı̆̆ıdır; mücbir sebebe istinaden belirli

10 Tamamı için bkz. Groth, "BGB § 206”, Münchener Kommentar zum BGB (8. Auflage, Beck 2018) N 4; benzer şekilde Eriş (n 4) 1218.

11 BGE 91 II 487; 100 II 142. 
bir mükellefiyetin ifasının askıya alınabilmesi için de sadece ilgili kişinin değil, aynı durumdaki başka kişilerin de söze konu engelin üstesinden gelemeyecek olmas1 beklenir. Ancak hemen ifade etmek gerekir ki, üstesinden gelmek şeklinde tezahür eden üçüncü alt unsurda mutlak manada bir imkânsızlıktan bahsedilmemekte, daha ziyade, engelin üstesinden gelinebilecek idiyse de ne pahasına gelinebileceği sorusunun yanitı aranmaktadır.

Bu söylenenler 1şığında güncel COVID-19 salgınının bir mücbir sebep olduğu ve bir çekin süresi içerisinde bankaya ibrazını engellediği söylenebilecek midir?

Evvel emirde ifade etmek gerekir ki, mücbir sebebin ilk iki unsuru dolayısıyla COVID-19 salgınının mücbir sebep niteliğinde tereddüt etmemek gerekir. Gerçekten de anılan salgın, herkesin etki alanı dışında oluşmuş, oluşmasında en azından çek hamillerinin herhangi bir kusurunun bulunmadığı bir hadisedir. Bu türden bir salgının küresel düzeyde ilk defa görülüyor oluşu, ani zuhur etmesi ve bu türden salgınların sık tekrar etmemesi, kişilerden bu yönde tedbirli bir davranışın da beklenememesi sonucunu doğurmaktadır. Bu manada COVID-19 salgınında çekin ibrazına yönelik engelleyici tedbirler alınması da hamillerden beklenemeyecektir.

Ancak tam da üçüncü alt unsurda, yani engelin üstesinden gelinebilmesi unsurunda tereddüt yaşanabilir. Nitekim görebildiğimiz kadarıyla yukarıda Dn 7'de alıntılanan eserlerde ve uygulamada banka ve hamillerde de tereddüdün tam olarak bu noktada yaşandığı görülmektedir. Türkiye'de ilk hasta 11 Mart 2020 tarihinde tespit edilmiş; sonrasında da kademeli olarak yurtdışından gelenlere 14 günlük karantina uygulanması, 65 yaş üzeri ve 20 yaş altı yurttaşlara sokağa çıkma yasağ1 getirilmesi, genel sokağa çıkma yasaklarının sınırlı süreyle ve banka tatil günlerine de denk gelmesi gibi normal hayatı sekteye uğratabilecek tedbirler alınmıştır. Ancak tüm bu tedbirlere rağmen, bankalar, sınırlı mesai ile de olsa, açık kalmıştır ve şehir içinde dolaşım da en azından 20-65 yaş arası kişiler için kısıtlanmamıştır. Bilindiği üzere hamil çeki, kendi bulunduğu şehir de dâhil olmak üzere, muhatap bankanın herhangi bir şubesine ibraz edebilmektedir ${ }^{12}$.

Bu noktada hamilin TK m 811 hükmünden istifade edebilmek için kendine has ve çekin ibrazını engelleyen hususları ve bunların üstesinden gelinemeyeceğini olası bir yargilamada dile getirmesi ve ispat etmesi gerekecektir ${ }^{13}$. Ancak hemen eklemek gerekir ki, üstesinden gelinememesi şeklinde tezahür eden alt unsurda kişiden kahramanlık yapması ve sinırları zorlaması da beklenmemektedir. Hamil belki, örneğin yaşı itibariyle bir banka şubesine gidebilecek durumdadır; ancak yukarıda da ifade olunduğu üzere burada sorulması gereken soru "ne pahasina" sorusudur ve kanaatimizce bu türden bulaşıcı ve sonuçları itibariyle ölüme varabilecek bir

\footnotetext{
Reisoğlu (n 4) 207.

13 Bkz. Yargıtay 12 HD, 13359/14549, 26.10.1995 (Kazancı İçtihat Bilgi Bankası).
} 
hastalık dışarıda kol gezerken, hamilden "hayatı pahasına", hayatını riske atarak çeki süresinde muhatap bankaya ibrazı beklenemez. Öyleyse, COVID-19 salgınının geneli itibariyle çekin süresi içerisinde bankaya ibrazına mani bir mücbir sebep olduğu kabul edilebilecektir.

Nitekim Alman Federal Mahkemesi'nin önüne gelen bir olayda davalı, 2. Dünya Savaşı sonrasında müttefik kuvvetlerin işgaline rağmen ibraz süreleri içerisinde sokağa çıkma yasağı olmadığını, banka şubesinin çalışmaya devam ettiğini ifade etse de, mahkeme hamil ve diğer herkes için mevcut tehlikeyi mücbir sebebin kabulü için yeterli görmüştür ${ }^{14}$.

Bu noktada son olarak şu hususu da eklemek gerekir: Yukarıda da ifade olunduğu üzere, somut olayda hamil mücbir sebebin varlı̆̆ını ve süresini ispat etmek durumundadır. Ancak 7226 sayılı Kanun'un yürürlüğe sokulmuş olması ve devletçe alınan diğer tedbirler mücbir sebebin varlığına karine teşkil edebileceği gibi, anılan Kanun'un Geçici 1. maddesinde zikredilen tarihler arasında da (13 Mart ve -eğer yeni bir uzatma olmazsa- 15 Haziran 2020 tarihleri arasında da) mücbir sebebin sürdüğ̈ hamil lehine kabul edilebilecektir. Bu hususların aksini ispat yükü müracaat borçlularında olduğu gibi, hamiller de bu sürelerin öncesinde veya sonrasında kendi özelleri bakımından mücbir sebebin varlığını ve devam ettiği hususlarını ayrıca ispata muhtaç olacaklardır.

\section{2. İhbar ve Kayıt Mükellefiyeti}

Yukarıda da ifade olunduğu üzere, TK m 811/1 hükmünde öngörülen ibraz sürelerinin kesilmesi sonucunun doğabilmesi için hamilin TK $m$ 811/2'de vaz edildiği şekliyle mücbir sebebi kendi cirantasına ihbar etmesi ve bu ihbarı çek üzerine veya alonja, yer ve tarih de belirtmek suretiyle kaydetmesi gerekmektedir. Anılan fikrada TK m 723 hükmüne yapılan atıf dolayısıyla anılan ihbarın noter kanalıyla yapılması gerekebilecektir.

Esasen bu ihbar ve kayıt mükellefiyeti kendi içerisinde bir çelişki barındırmaktadır. Şöyle ki; 1. fikra hamilin kendisinden kaynaklanmayan sebeplerle süresi içerisinde banka şubesine gidemediğini kabul etmekle ibraz sürelerini kesmektedir; ancak takip eden fikra aynı şahsın aynı süre içerisinde ve tehlike henüz geçmemişken notere gitmesini beklemektedir. Bu çelişki nedeniyledir ki, tahlile konu ihbar ve kayıt mükellefiyetinin işlevi ve zorunluluğu tartışllabilecek durumdadır.

Mevcut kaynaklarda bu ihbar mükellefiyetinin işlevi konusunda açıklık bulunmamaktadır. Ancak yukarıda Dn 14'te alıntılanan Federal Mahkeme kararının satır aralarından en azından Alman kanun koyucunun bazı hadiselerin herkesin

${ }_{14}$ Bkz. BGH, Urteil vom 22.10.1959 - II ZR 105/58. 
malumu olamayacă̆ı, herkesi aynı anda ve ölçüde etkileyemeyeceği, dolayısıyla cirantanın mücbir sebep teşkil eden hadiseden haberdar edilmesi gerektiği şeklinde bir düşünceye sahip olduğu anlaşılmaktadır. Hükmün 4. fikrasından da görülebildiği kadarıyla bu şart, mücbir sebebin en azından başlangıç tarihini işaretlemek adına da sevk edilmiş olabilir.

Her halükarda kanaatimizce COVID-19 salgını özelinde ileride ortaya çıkması muhtemel savunmalardan ilki bu türden bir ihbarın yapılmadığı ve/veya çek üzerine ilgili kaydın düşülmediği olabilecektir. Bu noktada da akla bu ihbar ve kayıt şartının mutlak olup olmadığı sorusu gelmektedir.

Burada temsil olunan görüş uyarınca anılan ihbar ve kayıt mükellefiyeti COVID-19 salgını özelinde mutlak değildir. Yukarıda da belirtildiği üzere, bu ihbar hamilin yaşadığı bir olgudan cirantanın haberinin olamayabileceği öngörüsü üzerine kuruludur. Ancak şu an ülkenin içinde bulunduğu durumda yediden yetmişe herkes olağanüstü bir halin yaşandığının, bunun normal hayatı sekteye uğrattığının farkındadır. Öyleyse kanaatimizce malumun ilanına da gerek bulunmamaktadır. Aynı şekilde 7226 sayılı Kanun'un Geçici 1. maddesi ile olası başlangıç ve bitiş tarihlerinin de tespit olunmuş olması, COVID-19 salgını özelinde tahlile konu ihbar ve kayıt şartını işlevsiz kılabilecektir. Bu noktada son olarak iki Alman mahkemesi kararına da değinmek gerekir:

Neustadt Yüksek Eyalet Mahkemesi önünde görülen bir olayda ${ }^{15}$ davacı tahlile konu ihbarın mümkün olmadığını, zaten anlamsız bir formalite olduğunu, başvuru hakkının kullanılmasına da mani olmadığını ifade etmiştir. Ancak mahkeme hükmün lafzının açık olduğunu, kıymetli evrakın şekil hukuku niteliğini ve hakkaniyete dayalı yoruma kapalı olduğunu ifade ile davacı iddialarını reddetmiştir. Yine de aynı mahkemenin AlmÇekK m 40 hükmüne (bizde TK m 808) atıfla davacıya mücbir sebep sona erdikten sonra yaptığı ihbarın tahlile konu ihbar yerine geçmesi şansını da tanıdığg görülmektedir. Anlaşılacağı üzere, Neustadt Yüksek Mahkemesi mücbir sebeple ilgili ihbar şartına şekilci yaklaşsa da, mücbir sebep sona erdikten sonra bankaya yapılan ibraz üzerine bankaca düşülen kayıt veya protestoyu da yeterli görmüştür. Buradan çıkan sonuç; ilgili mahkemenin (mücbir sebebin 15 günden fazla sürmesi halinde) bankaya ibraz olunmadan takibe geçebilmek için, sadece bu hal için ihtar ve kayıt şartını mutlak manada gördüğüdür.

Bamberg Yüksek Eyalet Mahkemesi ise ${ }^{16}$, bir başka olayda çek hamilinin tüm ilgililerin malumu olan bir mücbir sebepten çeki ibraz edememesi halinde, rücu hakkının kişiye haber verilmeden de kullanılabileceğini ifade ile yukarıda temsil olunan görüşe yaklaşmaktadır.

\footnotetext{
5 OLG Neustadt, Urteil vom 27.04.1948 - U 201/7.
}

16 OLG Bamberg, Urteil vom 04.03.1948 - U 94/47. 
Tüm bu söylenenler 1şı̆̆ında toparlamak gerekirse; kanaatimizce TK m 811/2 hükmünde yer verilen ihbar ve kayıt şartı mutlak değildir. Hamil, içinde bulunduğumuz COVID-19 salgınında olduğu gibi, ilgili herkesin malumu olan hallerde ihbar ve kayıt şartını yerine getirmeden de takibe geçebileceği gibi, mücbir sebep sona erdikten sonra doğrudan takibe geçmek yerine çeki bankaya ibraz etmek suretiyle ihmal ettiği ihbar ve kayıt şartını da tamamlayabilir.

\section{3. Çekin İbrazı}

Bu noktada son olarak TK m 811 hükmünde öngörülen nihai unsura, yani çekin ibrazına da değinmek gerekir. Hükmün 3. fikrası mücbir sebep sona erdikten sonra çekin bankaya ibraz edilmesini talep etmektedir. Ancak takip eden fikrada mücbir sebebin 15 günden fazla sürmesi halinde çek bankaya ibraz olunmaksızın da takibe geçilebileceği kural altına alınmaktadır.

Yukarıdaki açıklamalar 1şığında bu iki hüküm COVID-19 salgını özelinde değerlendirildiğinde, salgının yarattı̆̆ tehlike geçtikten sonra -bunun da 15 Haziran 2020 tarihi itibariyle genel anlamda gerçekleşebileceği öngörülmektedir; ancak kişi bazında ispat yükü kendisinde olmak üzere bu süre daha da uzayabilir- 2. fikrada öngörülen ihtarı çekebilmiş, kaydı düşebilmiş olan hamillerin çeki bankaya ibraz etmeden de takibe geçebilecekleri söylenebilecektir. Çünkü 4. fikrada öngörülen 15 günden uzun sürme şartı halihazırda gerçekleşmiştir. Her halükarda salgın tehlikesi sona erdikten itibaren çekin bankaya ibrazı salık verilir.

\section{Sonuç}

İşbu çalışma altında varılan tez ve sonuçları şu şekilde özetlemek mümkündür:

1. Çekin ibrazında yaşanabilecek gecikmelerde TK m 811 hükmü öncelikli olarak uygulama alanı bulur. Güncel COVID-19 salgını nedeniyle yürürlüğe giren 7226 sayılı Kanun'un Geçici 1. maddesi TK m 811 hükmünün yorumlanması ve tamamlanmasında kullanılabilir. Bu manada çek hamilleri mezkûr salgının mücbir sebep niteliğini ve süresini ispat dolayısıyla anılan kanundan istifade edebilirler.

2. TK m 811 hükmü çek hamillerini koruma amacıyla sevk edilmiş̧tir. Mücbir sebep dolayısıyla muhatap bankanın ve keşidecilerin konumu hükmün konusu değildir. Ancak muhatap banka ile keşideciler de genel hükümler üzerinden mücbir sebebe yaslanabilirler. Mücbir sebep, mücbir sebepten etkilenen kişinin mükellefiyetlerinin ifasının geçici süreyle imkânsız hale gelmesidir. Bu manada keşidecinin mücbir sebep süresince çek hesabında karşllık bulundurma yükümlülüğünün de askıya alındığı kabul edilebilir. Muhatap bankalar da bu süre zarfında kendilerine ibraz olunan çekler hakkında işlem tesis etmeksizin çekleri iade edebilirler. 
3. COVID-19 salgını hukuki manada çekin ibrazını engelleyen bir mücbir sebep olarak değerlendirilebilir. Bu süre zarfinda bankaların açık olması, geneli itibariyle bir sokağa çıkma yasağı olmaması bu değerlendirmeye etki etmez. Çünkü mücbir sebebe has "üstesinden gelinememezlik" unsuru kişinin her türden tehlikeyi göze alması anlamına gelmemektedir. Anılan unsurun tahlilinde "ne pahasına" sorusu sorulur.

4. TK $m 811 / 2$ hükmünde geçtiği haliyle ihbar ve kayıt şartı mutlak değildir. Herkesin malumu olan bir mücbir sebebin varlığı halinde veya mücbir sebep sona erdikten çekin bankaya ibraz edildiği hallerde anılan ihbar ve kayıt şartına uyulmamış olması hak kaybına neden olmaz. Güncel COVID-19 salgını dolayısıyla da ihbar ve kayıt şartının, kural olarak, aranmaması icap eder.

Hakem Değerlendirmesi: Dış bağımsız.

Çıkar Çatışması: Yazar çıkar çatışması bildirmemiştir.

Finansal Destek: Yazar bu çalışma için finansal destek almadığını beyan etmiştir.

Peer-review: Externally peer-reviewed.

Conflict of Interest: The author has no conflict of interest to declare.

Grant Support: The author declared that this study has received no financial support. 


\section{Bibliyografya/Bibliography}

Aydın A, "COVID-19 Salgını ve 7226 Sayılı Kanunun Geçici 1. Maddesi Çekten Kaynaklanan Hukuki Sorumluluğun Şartlarını Değiştirmiş midir?” https://blog.lexpera.com.tr/covid-19salgini-ve-7226-sayili-kanunun-gecici-1-maddesi-cekten-kaynaklanan-hukuki-sorumlulugunsartlarini-degistirmis-midir Erişim Tarihi 15.05.2020.

Bozer A ve Göle C, Klymetli Evrak Hukuku (7. Bas1, BTHAE 2017).

Bülow P, “Art. 48 ScheckG”, Wechselgesetz, Scheckgesetz (5. Auflage, Beck 2013).

Dannecker ve Biermann, Vorbemerkungen zu Art. 23 f: Unionsrechtliche Geldbussen und Zwangsgelder, Immenga/Mestmäcker, Wettbewerbsrecht (6. Auflage, Beck 2019).

Dural HA, “COVID-19 Salgını Nedeniyle Yürürlüğe Giren 7226 Sayılı Kanun’un Geçici 1. Maddesinin Çek Açısından Sonuçları" https://blog.lexpera.com.tr/covid-19-salgini-nedeniyle7226-sayili-kanunun-cek-acisindan-sonuclari Erişim Tarihi 15.05.2020.

Eriş G, Kıymetli Evrak (2. Baskı, Seçkin 2016).

Groth, "BGB § 206”, Münchener Kommentar zum BGB (8. Auflage, Beck 2018).

Kendigelen A, Çek Hukuku (5. Bas1, On İki Levha 2019).

Kuhn H, “Art. 1131”, CHK-Handkommentar zum Schweizerischen Privatrecht, (Orell Füssli 2016).

Öztan F, Klymetli Evrak Hukuku (17. Bas1, Turhan 2012).

Paslı A, "COVID-19 Salgınının Çek Hukukuna Etkisi: Güncel Koşullar Sürerken Çek İbrazı Mümkün müdür?” http://www.ticaretkanunu.net/ali-pasli-covid-19-salgininin-cek-hukukunaetkisi-guncel-kosullar-surerken-cek-ibrazi-mumkun-mudur Erişim Tarihi 15.05.2020.

Reisoğlu S, Çek Hukuku (1. Bask1, Cem 2011).

Ülgen H, Helvacı M, Kaya A ve Nomer Ertan, NF, Klymetli Evrak Hukuku (12. Bası, Vedat 2019). 